Western North American Naturalist 70(1), (C) 2010, pp. 26-38

\title{
DISTRIBUTION AND DYNAMICS OF WATERBIRD HABITAT DURING SPRING IN SOUTHERN OREGON-NORTHEASTERN CALIFORNIA
}

\author{
Joseph P. Fleskes ${ }^{1,3}$ and Christopher J. Gregory ${ }^{1,2}$
}

\begin{abstract}
The southern Oregon-northeastern California and extreme northwestern Nevada (hereafter "SONEC") region provides critical spring migration habitat for waterfowl and other waterbirds in the Pacific Flyway. Information on the dynamics and distribution of waterbird habitats in SONEC during spring is needed to guide conservation efforts in the region. We grouped 1992 National Land Cover Data classes into 5 potential waterbird habitat types and used Landsat 5 Thematic Mapper and Landsat 7 Enhanced Thematic Mapper Plus satellite imagery to map flooding of these habitat types in SONEC during February-May, 2002 and 2003. SONEC included 13,727 km² of potential waterbird habitat comprised of grasslands $(37.1 \%)$, pasture/hay $(24.6 \%)$, marsh $(15.9 \%)$, open wetland $(11.8 \%)$, and croplands $(10.6 \%)$. On average, $11.9 \%$ of this potential habitat was flooded during spring; but the percentage, area, and composition varied within and among years and subregions. Total flooding increased from $693 \mathrm{~km}^{2}$ in February to $2099 \mathrm{~km}^{2}$ in April during 2002 and from $1630 \mathrm{~km}^{2}$ in February to $2125 \mathrm{~km}^{2}$ in May during 2003. Open wetland comprised 58\%-74\%, marsh $8 \%-18 \%$, pasture/hay $4 \%-11 \%$, grassland $4 \%-17 \%$, and cropland $3 \%-8 \%$ of the flooded habitat in SONEC. Satellite imagery and land-use data provided useful estimates of waterbird habitat availability in SONEC during spring, but other methods should be tested to more accurately measure flooding of densely vegetated habitats such as marsh. With $<12 \%$ of the potential habitat flooded on average during spring, conservation programs have ample opportunity to improve the SONEC landscape for migrating waterbirds.
\end{abstract}

Key words: Landsat, spring habitat, waterfowl, waterbirds, Great Basin, Oregon, California.

The southern Oregon-northeastern California and extreme northwestern Nevada (hereafter "SONEC") region (Fig. 1a) of the Great Basin provides critical spring migration habitat for waterfowl and other waterbirds in the Pacific Flyway. Fleskes and Yee (2007) reported peak counts of over 2 million waterfowl in SONEC during mid-March, with Northern Pintails (Anas acuta), a species of special concern because of its continued low population numbers (Miller and Duncan 1999, USFWS 2009), as the most abundant species. Miller et al. (2005) reported that $77 \%-87 \%$ of female Northern Pintails equipped with satellite transmitters during late winter in the Central Valley of California visited SONEC during spring on their way to Alaska and Prairie Parkland breeding areas. Pintails are an early-nesting species and endogenous fat and protein reserves gathered during migration play a critical role in formation of eggs for their initial nesting effort (Krapu 1974, Esler and Grand 1994). Thus, conservation of spring migration habitats in SONEC is important for many Pacific Flyway waterbirds (Lindstrom 2003) and is especially critical for early-nesting species such as pintails.

Information on the dynamics and distribution of waterbird habitats in SONEC during spring is needed to guide the Intermountain West Joint Venture and other conservation efforts in the region (North American Waterfowl Management Plan Committee 2004, Intermountain West Joint Venture [Internet]). Conservation planning requires knowledge of the carrying capacity of the current landscape and potential for increasing that capacity through management. Understanding the geographic distribution and temporal variation of waterbird habitats is crucial for setting goals and identifying potential habitats for protection, enhancement, and restoration. Global climate change may alter the timing and amounts of rain, snow, and snowmelt (Cayan et al. 2008), which could greatly impact availability of waterbird habitats during spring in SONEC. An understanding of the current landscape is needed to evaluate these impacts. Although maps of wetland basins and other National Land Cover Data (NLCD) types are available

\footnotetext{
${ }^{1}$ U.S. Geological Survey, Western Ecological Research Center, 6924 Tremont Road, Dixon, CA 95620

${ }^{2}$ Present address: Environmental Futures Centre, School of Environment, Griffith University, Gold Coast Campus, Queensland, 4222, Australia ${ }^{3}$ E-mail: joe_fleskes@usgs.gov
} 
(Dahl 2000, USGS EROS [Internet][a]), wetland basins only provide habitat for waterbirds when they contain water. Also, croplands, pastures, hayfields, and grasslands are important waterbird habitats when flooded (Fleskes and Battaglia 2004); and the flooded extent of these areas in SONEC has not been mapped. The combined analysis of satellite imagery and land-use data has been used successfully to map availability of waterbird habitats elsewhere (Spell et al. 1995, Fleskes et al. 2005), but the method has not been tested in SONEC. To provide baseline data, test the utility of a method for evaluating changes related to climate change and other factors, and help guide conservation efforts in SONEC, we grouped NLCD classes (based on 1991-1993 [hereafter 1992] classification) into 5 potential waterbird habitat types (open wetlands, marsh, croplands, pasture/hay, and grasslands) and used Landsat 5 Thematic Mapper (TM) and Landsat 7 Enhanced Thematic Mapper Plus (ETM+) satellite imagery (USGS EROS [Internet][b]) to map flooding of these habitats during spring (February-May) 2002 and 2003.

\section{Study Area}

\section{Overview of SONEC}

SONEC includes all major wetland complexes in the intermountain reaches of southern Oregon, northeastern California, and extreme northwestern Nevada (Fig. 1) in the northwestern portion of the Great Basin (Hunt 1967). SONEC comprises approximately $10 \%$ of the Great Basin, extending about $480 \mathrm{~km}$ east to west and $400 \mathrm{~km}$ north to south, and encompassing 70,490 km². Major uplifted areas run predominantly north and south, with most wetland habitats in basins. The area of waterbird habitat available during spring is largely dependent on the amount of spring rains and run-off from accumulated snow that naturally floods or is applied to wetlands, pastures, and other landscapes (Ivey and Paullin 1985). Freezing temperatures commonly reduce availability of waterbird habitats during winter and early spring.

\section{Subregions}

The SONEC region originally was defined, based on roads and topographic features, to contain 7 subregions (Fleskes and Battaglia 2002); however, 4 peripheral subregions (Surprise
Valley, Shasta Valley, Pueblo Valley, and Honey Lake) were added so the region encompassed all locations of migrating radio-tagged Northern Pintails (Miller et al. 2003, Fleskes and Battaglia 2004). The Lower Klamath subregion includes Lower Klamath and Tule Lake National Wildlife Refuges (NWRs), Butte Valley Wildlife Area, Klamath River Game Management Area, Clear Lake NWR, and numerous small reservoirs and wetlands (Bottorff 1985). The Upper Klamath subregion includes Upper Klamath Lake, Agency Lake, Sycan Marsh, Klamath Marsh, and the Williamson River Ranch. The Modoc Plateau subregion includes Goose Lake, Modoc NWR, Fairchild Swamp, and other wetlands in the Devils Garden area of the Modoc National Forest. The Northeast California subregion includes Fall River Valley, Big Valley, and Ash Creek Wildlife Area. The Warner Valley subregion includes Hart Mountain NWR, but most waterbird habitat is found within Warner Valley. The Summer Lake subregion includes the Chewaucan Marsh, Summer Lake Wildlife Area, and Lake Abert. The Malheur subregion includes the Harney Basin, the Silvies and Blitzen River drainages, and Malheur NWR. The main waterbird habitats in the Surprise Valley subregion are the Lower, Middle, and Upper Alkali Lakes. Shasta Valley Wildlife Area is the main waterfowl area in the Shasta Valley subregion. Alvord Lake and scattered wetlands in the north central part of the subregion are the main waterbird habitats in the Pueblo Valley subregion. Honey Lake and associated marshes in the southern tip of the Honey Lake subregion are the main waterbird habitats in that subregion.

\section{Climate and Weather}

SONEC's climate is characterized by relatively dry, warm summers and wet, cold winters. Maximum temperatures average $33{ }^{\circ} \mathrm{C}$ $\left(91{ }^{\circ} \mathrm{F}\right)$ during the summer, with winter minimums averaging $-7.2^{\circ} \mathrm{C}\left(19^{\circ} \mathrm{F}\right)$. Precipitation occurs throughout the year but most (e.g., $70 \%$ in Klamath Falls, OR) occurs from November through April (Oregon Climate Service [Internet]). The complex topography of SONEC results in highly variable and localized climate conditions (WRCC [Internet][a], [Internet][b]).

Near-average weather conditions prevailed in both years of the study. Spring temperatures during 2002 and 2003 were similar to longterm averages (LTA) for most SONEC sites, 

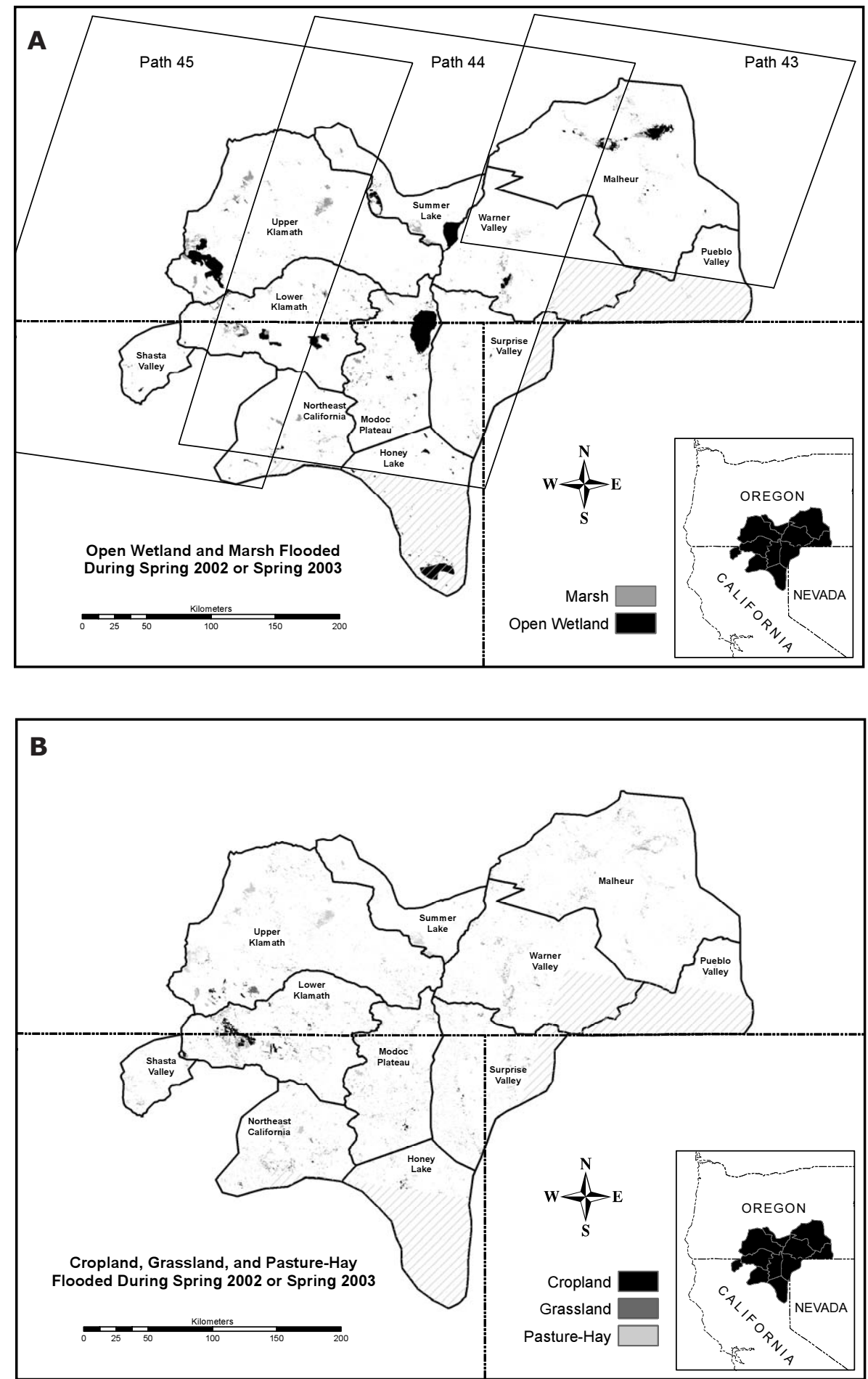

Fig. 1. Southern Oregon-northeastern California and extreme northwestern Nevada (SONEC) region comprising Landsat 5 Thematic Mapper and Landsat 7 Enhanced Thematic Mapper Plus imagery from path 43, 44, and 45 (coverage in areas outside imagery coverage (cross-hatched) was predicted based on flooding in coverage areas: (A) marsh and time during February-May, 2002 or 2003; (C) marsh and open wetland not flooded during February-May, 2002 or 2003; 

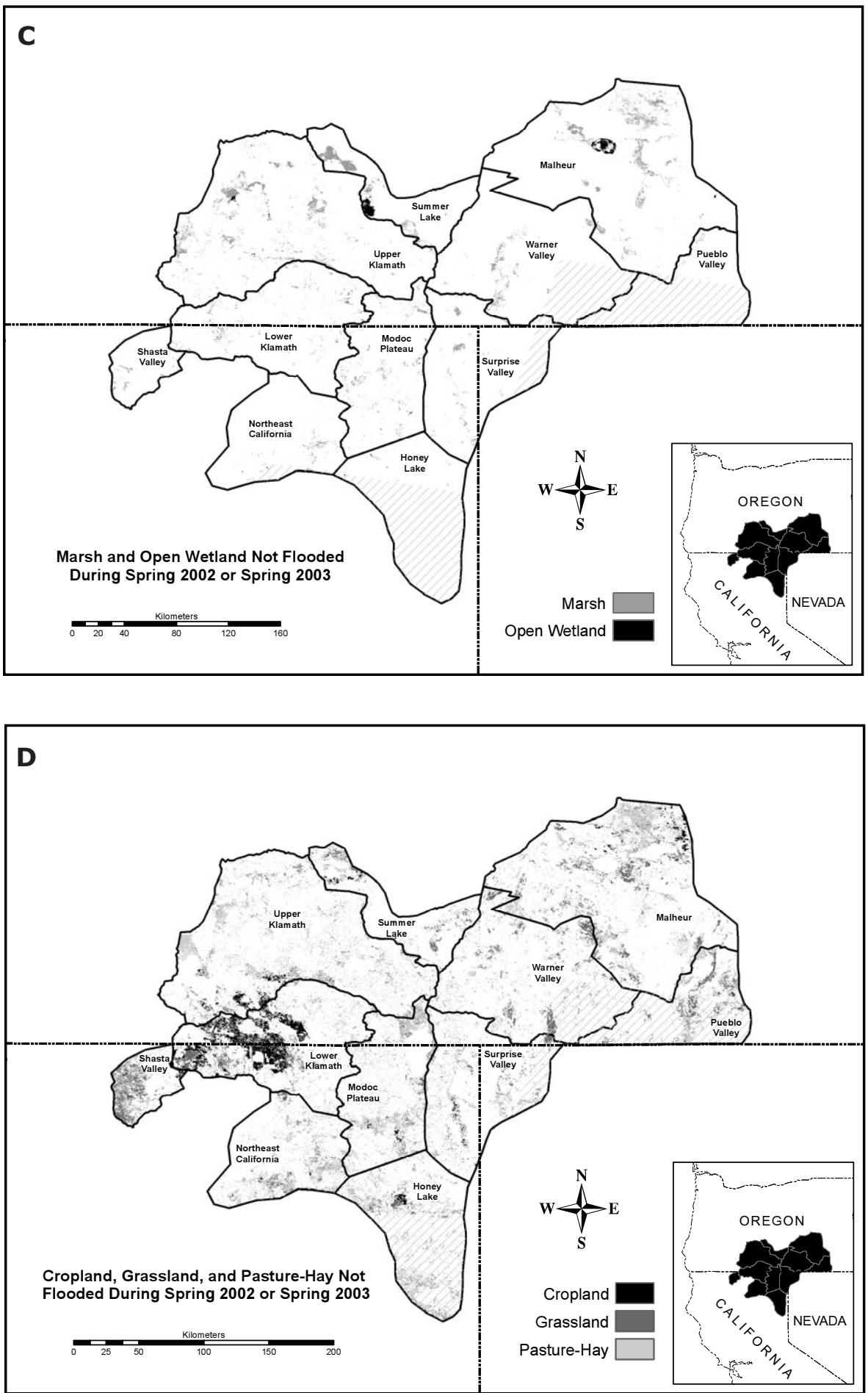

10 subregions. National Land Cover Data (1992) classes were grouped into 5 potential waterbird habitat types and shown in panel A) were used to map flooding of these habitat types during February-May, 2002 and 2003. Flooding open wetland flooded any time during February-May, 2002-2003; (B) cropland, grassland, and pasture/hay flooded any and (D) cropland, grassland, and pasture/hay not flooded any time during February-May, 2002 or 2003. 
TABLE 1. Landsat imagery used to map flooding of waterbird habitat in southern Oregon-northeastern California-extreme northwestern Nevada (SONEC) during February-May 2002-2003.

\begin{tabular}{|c|c|c|c|c|c|c|}
\hline Year & Scene-date & $\begin{array}{l}\text { Path } 43 \\
\text { Row } 30\end{array}$ & $\begin{array}{l}\text { Path } 44 \\
\text { Row } 30\end{array}$ & $\begin{array}{l}\text { Path } 44 \\
\text { Row } 31\end{array}$ & $\begin{array}{l}\text { Path } 45 \\
\text { Row } 30\end{array}$ & $\begin{array}{l}\text { Path } 45 \\
\text { Row } 31\end{array}$ \\
\hline 2002 & $\begin{array}{l}2002 \text { February } \\
2002 \text { March } \\
\text { 2002 April } \\
\text { 2002 May }\end{array}$ & $\begin{array}{l}14 \text { February } \\
2 \text { March } \\
3 \text { April } \\
-\end{array}$ & $\begin{array}{l}5 \text { February } \\
- \\
26 \text { April } \\
12 \text { May }\end{array}$ & $\begin{array}{l}5 \text { February } \\
- \\
26 \text { April } \\
12 \text { May }\end{array}$ & $\begin{array}{l}12 \text { February } \\
- \\
1 \text { April } \\
3 \text { May }\end{array}$ & $\begin{array}{l}12 \text { February } \\
- \\
1 \text { April } \\
3 \text { May }\end{array}$ \\
\hline 2003 & $\begin{array}{l}2003 \text { February } \\
2003 \text { March } \\
\text { - } \\
2003 \text { May }\end{array}$ & $\begin{array}{l}9 \text { Februarya } \\
- \\
24 \text { May }\end{array}$ & $\begin{array}{l}8 \text { February } \\
28 \text { March } \\
- \\
15 \text { May }\end{array}$ & $\begin{array}{l}8 \text { February } \\
28 \text { March } \\
- \\
15 \text { May }\end{array}$ & $\begin{array}{c}7 \text { Februarya } \\
- \\
22 \text { May }\end{array}$ & $\begin{array}{c}7 \text { Februarya } \\
- \\
22 \text { May }\end{array}$ \\
\hline
\end{tabular}

aDerived from Landsat 5 TM sensors; other 24 images derived from Lansat 7 ETM+ sensors.

with the exception of warmer-than-average January 2003 temperatures throughout SONEC (e.g., daily mean at selected sites averaged $0.6-4.9^{\circ} \mathrm{C}$ in 2003 versus $-3.9-0.4^{\circ} \mathrm{C}$ for LTA) and colder-than-average April 2003 temperatures in the western portion of SONEC (e.g., daily mean at selected sites averaged 3.5-5.0 ${ }^{\circ} \mathrm{C}$ in 2003 versus $6.0-7.6{ }^{\circ} \mathrm{C}$ for LTA) (WRCC [Internet][c], Fleskes and Battaglia 2004). The standardized precipitation index (SPI) in the High Plateau and South Central Oregon climatic divisions that encompassed most of SONEC were near the 109-year average (i.e., near normal) for the 6 months (1 August 2001 to 31 January 2002) preceding the 2002 spring, the core 3-month spring period (1 February to 30 April 2002), and the entire 9-month period (1 August 2001 to 30 April 2002; WRCC $[$ Internet $][\mathrm{d}])$. The SPI was moderately dry in both climatic divisions for the 6 months (1 August 2002 to 31 January 2003) preceding the 2003 spring but was near normal for the core 3-month spring period and averaged near normal for the entire 9-month period ending on 30 April 2003.

\section{MEthods}

We grouped 1992 NLCD classes into 5 potential waterbird habitat types and used TM and ETM + satellite imagery to map flooding of these habitat types in SONEC during February-May, 2002 and 2003. The 1992 NLCD raster data sets are divided into 21 use-cover classes based primarily on unsupervised classification of Landsat Thematic Mapper 1991-1993 imagery as well as on topography, census data, agricultural statistics, soil characteristics, other land-use maps, and wetlands data (Vogelmann et al. 1998). We overlaid and clipped the original NLCD raster layers (USGS EROS
[Internet $][a]$ ) with the SONEC region and subregion boundaries. Two NLCD classes were not found in SONEC (fallow and high-intensity residential), and we excluded classes that were not potential waterbird habitat (low-intensity residential, commercial/industrial/transportation, bare rock/sand/clay, transitional [barren], deciduous forest, evergreen forest, mixed forest, shrubland, orchards/vineyards/other, and urban/recreational grasses). We grouped all other NLCD classes into 5 waterbird habitats: (1) small grains or row crops = cropland; (2) grassland/herbaceous = grassland; (3) pasture/hay = pasture/hay; (4) emergent herbaceous wetland or woody wetland = marsh; and (5) open water, quarries, or gravel pits = open wetland.

After reviewing all Worldwide Reference System-2 TM and ETM + scenes (Landsat imagery specific to a place and date) of the SONEC area (path/row: 43/30, 44/30, 44/31, 45/30, and 45/31) during February-May, 2002 and 2003 (USGS EROS [Internet][b]), we purchased the 15 scenes during 2002 and the 12 scenes during 2003 that were clear enough of cloud cover to allow analysis (Table 1). According to metadata included with the original 27 Landsat images, 17 images were cloud free or nearly cloud free, 6 images contained about $15 \%$ cloud cover, and 4 images contained about 30\% cloud cover. Clipping the original Landsat images to the SONEC boundary (see below) reduced overall cloud cover. We grouped scenes by date into 7 scene-dates for analysis (Table 1). Most interpretation of our data comes from the 4 scene-dates (2002: February, April; 2003: February, May) where all 3 paths were available (Table 1).

Of the 27 images we used, 3 were derived from TM sensors (Path 43 [row 30] 9 February 
2003 and Path 45 [rows 30 and 31] 7 February 2003), and the other 24 were derived from $\mathrm{ETM}+$ sensors. The ETM + instrument is a fixed 8-band, multispectral scanning radiometer that provides imagery representing an area up to $183 \mathrm{~km}$ wide by $170 \mathrm{~km}$ long (NASA [Internet][a]). Likewise, the TM instrument allows simultaneous multispectral scanning of areas up to $185 \mathrm{~km}$ wide by $172 \mathrm{~km}$ long (NASA [Internet][b]). Each rectangular TM and ETM + scene was delivered in a series of TIF-image files, with each TIF-image file representing a different spectral band. Spectral widths were identical or nearly identical between corresponding bands recorded by the TM and ETM + instruments (NASA [Internet][a], [Internet][b]). We combined bands 1-5 and 7 ( 1 pixel $\left.=30 \mathrm{~m}^{2}\right)$ of each $\mathrm{TM}$ and $\mathrm{ETM}+$ scene to form a single color composite image. We then intersected the image with the SONEC coverage and excluded areas outside the SONEC boundary.

To associate unique spectral signatures with broad reflectance types in each new image, we used ERDAS Imagine (Version 8.7) and chose the classification options of (a) unsupervised cluster analysis, (b) 20 classes, and (c) iteration until $95 \%$ convergence. Our choice of 20 classes accurately captured the spectral diversity (and associated water content) of the underlying imagery while still consisting of few enough classes to make subsequent reclassification steps simple and less time-consuming. This multivariate cluster analysis procedure created homogenous groups, minimized human error in interpretation and classification, reduced the need for ground-truthing, required no prior knowledge of the study area, and was relatively inexpensive compared with other methods (e.g., procurement of aerial photography and extensive ground-truthing). For easier identification of water and ice, we displayed the output using a color composite of TM and ETM + bands 4, 5, and 3. We grouped the 20 classes into 4 reflectance types of interest: cloud or dune, snow or ice, water or shadow, and other. As noted above, we avoided scenes with clouds in the SONEC region to minimize this main source of shadow (and potential error). After further examination and image correction, we discovered a fifth reflectance type, which, based on site data, we determined to be alkali flats. Using the Raster Calculator of the Spatial Analyst extension of ArcMap
(Version 8.3), we combined the intersection of each clipped, classified TM and ETM + raster layer with the corresponding clipped NLCD raster layer to create a new raster layer whose values represented unique pairings of NLCD and TM or ETM+ values.

Because path 44 slightly overlaps paths 43 and 45 (Fig. 1a), we clipped overlap areas from each path using the Raster Calculator of the Spatial Analyst extension of ArcMap (Version 8.3). In all, we created 16 full and 8 overlap raster layers for analysis. We georeferenced rasters to 1983 North American datum, zone 10 (for paths 44, 45, and overlaps) or zone 11 (for path 43) of the Universal Transverse Mercator (UTM) coordinate system. We performed all analyses using a Dell Precision 530 personal computer running Windows 2000 operational software. We completed raster-based (GIS) image analyses, classifications, processing, and other GIS procedures using ERDAS Imagine (Version 8.7) and the Spatial Analyst extension of ArcMap (Version 8.3). We exported final tabular data to Microsoft Excel 2002 for analysis.

We classified areas that showed water reflectance as "flooded" (previously our "water or shadow”). We used refuge records (D. Mauser, U.S. Fish and Wildlife Service, unpublished data) to verify our correct classification of 10 flooded and 10 dry units on Lower Klamath NWR. Frozen areas had different reflectance than water. Because we did not consider frozen areas as waterbird habitat, we classified them as ice and did not include them in the flooded total. Using simple algebra, we calculated total flooded area within SONEC and within each SONEC subregion for each month from flooded values (each cell $=30 \mathrm{~m}^{2}$ ) using the following formula:

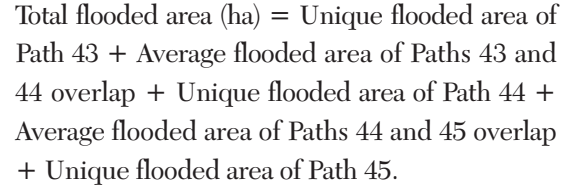

Because we purchased and began processing imagery before the 4 peripheral subregions were added to SONEC, significant portions of some of these subregions were outside the area covered by Paths $43-45$ that we used to map flooding. We provide estimates of the area of each habitat that was within and outside our coverage area and predict flooding of 
TABLE 2. Waterbird habitat in southern Oregon-northeastern California and extreme northwestern Nevada (SONEC) subregions during spring 2002-2003. Information includes subregion area and percentage of each subregion mapped for flooding (map\%) potential habitat types (Type), percent of subregion comprised of each type (SR\%), area of each type (Area), percent of each type mapped for flooding (PHmap\%), average percent of each type that was flooded during February-May, 2002 and 2003 (AvgF\%), and area of flooded habitat during 2002 (February [Feb02] and April [Apr02]) and 2003 (February [Feb03] and May [May03]).

\begin{tabular}{|c|c|c|c|c|c|c|c|c|c|}
\hline \multirow{2}{*}{$\begin{array}{l}\text { Subregion } \\
\quad(\text { area; map\%) }\end{array}$} & \multicolumn{5}{|c|}{ Potential habitat } & \multicolumn{4}{|c|}{ Flooded habitat (ha) ${ }^{a}$} \\
\hline & Type $^{\mathrm{b}}$ & $\mathrm{SR} \%$ & Area (ha) & PHmap\% & $\operatorname{AvgF} \%$ & Feb02 & Apr02 & Feb03 & May03 \\
\hline \multicolumn{10}{|c|}{ Honey Lake $(576,041$ ha; $35 \%)$} \\
\hline & Crop & 0.5 & 2852 & 81 & 6.5 & 235 & 12 & 0 & 495 \\
\hline & Grass & 7.0 & 40,395 & 29 & 3.5 & 1394 & 1498 & 132 & 2686 \\
\hline & Marsh & 0.2 & 1384 & 50 & 5.4 & 30 & 134 & 17 & 120 \\
\hline & Wetld & 3.4 & 19,454 & 11 & 55.2 & 177 & 14,301 & 12,739 & 15,715 \\
\hline & PasHay & 2.8 & 16,086 & 32 & 3.8 & 246 & 876 & 10 & 1314 \\
\hline & TOTAL & 13.9 & 80,170 & 28 & 16.3 & 2082 & 16,820 & 12,898 & 20,330 \\
\hline \multicolumn{10}{|c|}{ Lower Klamath (693,552 ha; $100 \%)$} \\
\hline & Crop & 14.3 & 99,369 & 100 & 6.1 & 2381 & 5143 & 11,687 & 4889 \\
\hline & Grass & 8.3 & 57,235 & 100 & 2.9 & 801 & 2063 & 1571 & 2134 \\
\hline & Marsh & 3.2 & 22,349 & 100 & 20.1 & 1189 & 5685 & 4868 & 6249 \\
\hline & Wetld & 2.2 & 15,514 & 100 & 58.6 & 2154 & 12,878 & 9989 & 11,341 \\
\hline & PasHay & 4.9 & 33,648 & 100 & 1.9 & 399 & 632 & 898 & 578 \\
\hline & TOTAL & 32.9 & 228,114 & 100 & 9.6 & 6923 & 26,400 & 29,014 & 25,191 \\
\hline \multicolumn{10}{|c|}{ Malheur $(1,208,047$ ha; $99 \%)$} \\
\hline & Crop & 0.8 & 10,017 & 100 & 1.3 & 130 & 136 & 31 & 233 \\
\hline & Grass & 7.3 & 88,129 & 100 & 1.9 & 1369 & 2812 & 1050 & 1310 \\
\hline & Marsh & 3.8 & 45,338 & 100 & 5.4 & 1521 & 4874 & 464 & 2972 \\
\hline & Wetld & 2.2 & 26,475 & 100 & 56.8 & 11,388 & 21,131 & 14,745 & 12,834 \\
\hline & PasHay & 6.1 & 73,394 & 100 & 3.0 & 354 & 3308 & 266 & 4928 \\
\hline & TOTAL & 20.1 & 243,353 & 100 & 8.8 & 14,763 & 32,261 & 16,558 & 22,277 \\
\hline \multicolumn{10}{|c|}{ Modoc Plateau (533,039 ha; $100 \%)$} \\
\hline & Crop & 1.1 & 5954 & 100 & 6.5 & 195 & 669 & 13.5 & 680 \\
\hline & Grass & 5.8 & 31,060 & 100 & 5.0 & 1093 & 2070 & 363 & 2694 \\
\hline & Marsh & 3.8 & 20,230 & 100 & 16.2 & 514 & 5146 & 1270 & 6191 \\
\hline & Wetld & 7.3 & 39,118 & 100 & 64.9 & 264 & 31,604 & 36,077 & 33,573 \\
\hline & PasHay & 10.7 & 57,254 & 100 & 3.4 & 1888 & 1558 & 96 & 4236 \\
\hline & TOTAL & 28.8 & 153,616 & 100 & 21.2 & 3954 & 41,047 & 37,820 & 47,374 \\
\hline \multicolumn{10}{|c|}{ Northeastern California (479,925 ha; $95 \%)$} \\
\hline & Crop & 0.5 & 2375 & 90 & 8.2 & 486 & 93 & 51 & 151 \\
\hline & Grass & 7.4 & 35,749 & 88 & 5.0 & 2915 & 1367 & 774 & 2124 \\
\hline & Marsh & 1.5 & 7132 & 100 & 22.1 & 204 & 1655 & 1676 & 2769 \\
\hline & Wetld & 0.5 & 2626 & 90 & 41.1 & 973 & 1008 & 806 & 1531 \\
\hline & PasHay & 6.9 & 33,141 & 90 & 6.2 & 3544 & 1358 & 978 & 2346 \\
\hline & TOTAL & 16.9 & 81,023 & 90 & 8.3 & 8122 & 5480 & 4285 & 8922 \\
\hline \multicolumn{10}{|c|}{ Pueblo Valley $(402,255$ ha; $31 \%)$} \\
\hline & Crop & 0.1 & 410 & 96 & 0.3 & 0 & 0 & 0.0 & 5 \\
\hline & Grass & 9.5 & 38,382 & 46 & 0.3 & 141 & 88 & 210 & 9 \\
\hline & Marsh & 0.3 & 1207 & 69 & 1.0 & 7 & 29 & 1 & 13 \\
\hline & Wetld & 0 & 80 & 51 & 7.9 & 8 & 10 & 0 & 7 \\
\hline & PasHay & 2.7 & 10,999 & 40 & 0.3 & 20 & 96 & 2 & 33 \\
\hline & TOTAL & 12.7 & 51,078 & 46 & 0.3 & 176 & 223 & 212 & 67 \\
\hline \multicolumn{10}{|c|}{ Shasta Valley $(175,171$ ha; $100 \%)$} \\
\hline & Crop & 1.5 & 2558 & 100 & 1.0 & 55 & 8 & 36 & 1 \\
\hline & Grass & 22.0 & 38,479 & 100 & 1.3 & 673 & 202 & 808 & 373 \\
\hline & Marsh & 2.8 & 4829 & 100 & 3.4 & 124 & 182 & 41 & 306 \\
\hline & Wetld & 0.4 & 760 & 100 & 62.3 & 634 & 556 & 161 & 543 \\
\hline & PasHay & 7.3 & 12,717 & 100 & 0.5 & 149 & 20 & 53 & 20 \\
\hline & TOTAL & 33.9 & 59,343 & 100 & 2.1 & 1634 & 968 & 1100 & 1243 \\
\hline
\end{tabular}


TABLE 2. Continued.

\begin{tabular}{|c|c|c|c|c|c|c|c|c|c|}
\hline \multirow[b]{2}{*}{$\begin{array}{l}\text { Subregion } \\
\quad(\text { area; map \%) }\end{array}$} & \multicolumn{5}{|c|}{ Potential habitat } & \multicolumn{4}{|c|}{ Flooded habitat (ha) ${ }^{a}$} \\
\hline & Type $^{\mathrm{b}}$ & SR\% & Area (ha) & РНmap\% & AvgF\% & Feb02 & Apr02 & Feb03 & May03 \\
\hline \multicolumn{10}{|c|}{ Summer Lake (307,204 ha; $100 \%)$} \\
\hline & Crop & 0.6 & 1879 & 100 & 0.2 & 2 & 2 & 5 & 8 \\
\hline & Grass & 6.3 & 19,260 & 100 & 0.9 & 69 & 327 & 85 & 215 \\
\hline & Marsh & 7.6 & 23,451 & 100 & 7.0 & 580 & 1722 & 285 & 3989 \\
\hline & Wetld & 7.5 & 23,022 & 100 & 86.4 & 18,071 & 20,999 & 18,847 & 21,636 \\
\hline & PasHay & 4.5 & 13,952 & 100 & 5.9 & 288 & 790 & 234 & 2004 \\
\hline & TOTAL & 26.6 & 81,564 & 100 & 27.6 & 19,010 & 23,840 & 19,456 & 27,852 \\
\hline \multicolumn{10}{|c|}{ Surprise Valley $(625,284 \mathrm{ha} ; 89 \%)$} \\
\hline & Crop & 0.5 & 3166 & 100 & 4.8 & 16 & 273 & 0 & 315 \\
\hline & Grass & 5.7 & 35,610 & 86 & 3.9 & 2181 & 1591 & 218 & 1581 \\
\hline & Marsh & 1.7 & 10,874 & 99 & 6.0 & 430 & 898 & 113 & 1159 \\
\hline & Wetld & 0.1 & 786 & 100 & 33.2 & 42 & 407 & 178 & 417 \\
\hline & PasHay & 3.6 & 22,334 & 88 & 3.6 & 259 & 1202 & 3 & 1711 \\
\hline & TOTAL & 11.6 & 72,770 & 89 & 4.5 & 2928 & 4371 & 5134 & 5183 \\
\hline \multicolumn{10}{|c|}{ Upper Klamath (1,213,985 ha; $100 \%)$} \\
\hline & Crop & 1.4 & 16,734 & 100 & 4.8 & 434 & 891 & 1551 & 354 \\
\hline & Grass & 5.4 & 65,580 & 100 & 2.5 & 370 & 3348 & 1260 & 1564 \\
\hline & Marsh & 5.3 & 64,163 & 100 & 10.8 & 139 & 10,363 & 5472 & 11,697 \\
\hline & Wetld & 2.5 & 30,797 & 100 & 70.1 & 5483 & 28,291 & 24,585 & 27,948 \\
\hline & PasHay & 4.4 & 53,618 & 100 & 7.0 & 152 & 5571 & 4511 & 4758 \\
\hline & TOTAL & 19.0 & 230,892 & 100 & 19.0 & 6578 & 48,464 & 37,379 & 46,322 \\
\hline \multicolumn{10}{|c|}{ Warner Valley $(834,556$ ha; $79 \%)$} \\
\hline & Crop & $<0.1$ & 83 & 100 & 9.1 & 2 & 12 & 2 & 14 \\
\hline & Grass & 7.1 & 59,133 & 82 & 2.3 & 912 & 2436 & 342 & 1771 \\
\hline & Marsh & 2.1 & 17,796 & 98 & 11.0 & 970 & 3515 & 521 & 2843 \\
\hline & Wetld & 0.4 & 3211 & 99 & 72.5 & 1203 & 2999 & 2798 & 2308 \\
\hline & PasHay & 1.3 & 10,506 & 100 & 4.7 & 82 & 1053 & 56 & 801 \\
\hline & TOTAL & 10.9 & 90,729 & 88 & 6.8 & 3169 & 10,016 & 3720 & 7736 \\
\hline \multicolumn{10}{|c|}{ SONEC Total $(7,049,059$ ha; $87 \%)$} \\
\hline & Crop & 2.1 & 145,397 & 99 & 5.4 & 3935 & 7238 & 13,377 & 7146 \\
\hline & Grass & 7.2 & 509,012 & 86 & 2.6 & 11,917 & 17,803 & 6813 & 16,462 \\
\hline & Marsh & 3.1 & 218,753 & 99 & 10.6 & 5708 & 34,202 & 14,729 & 38,308 \\
\hline & Wetld & 2.3 & 161,844 & 89 & 65.4 & 40,400 & 134,184 & 120,929 & 127,850 \\
\hline & PasHay & 4.8 & 337,647 & 93 & 4.0 & 7381 & 16,463 & 7107 & 22,730 \\
\hline & TOTAL & 19.5 & $1,372,653$ & 92 & 11.9 & 69,340 & 209,890 & 162,955 & 212,496 \\
\hline
\end{tabular}

ancludes extrapolated estimate for area outside Paths 43-45 coverage used for flood mapping.

${ }^{b}$ Crop $=$ cropland, Grass $=$ Grassland, Wetld $=$ open wetland, PasHay $=$ pasture/hay.

habitats outside our coverage area by assuming that the flooded percentage of each habitat outside our coverage area was the same as in the rest of the subregion (or adjacent subregion if none in that subregion).

\section{RESULTS}

\section{Coverage of TM and ETM+ Imagery}

The TM and ETM+ satellite imagery we selected (Table 1) covered $87 \%$ of the entire area of SONEC, including all, or nearly all subregions except Honey Lake and Pueblo Valley (Fig. 1a, Table 2). This coverage allowed us to map for flooding in $92 \%$ of the potential waterbird habitat (86\%-99\% of each type) in SONEC (Fig. la, Table 2). Potential waterbird habitat in SONEC outside of where we mapped flooding (and for which we predicted flooding based on mapped areas) totaled 113,930 ha and was in the Honey Lake (58,043 ha), Pueblo Valley (27,582 ha), Warner Valley (11,069 ha), Northeastern California (8264 ha), Surprise Valley (7859 ha), and Malheur (2433 ha) subregions. Other than the 17,236-ha Honey Lake, only 330 ha of open wetland and 1499 ha of marsh were outside where we mapped flooding; the other 94,285 ha of potential waterbird 
habitat was uplands (i.e., grasslands, pasture/hay, cropland).

\section{Potential Waterbird Habitat}

SONEC included $13,727 \mathrm{~km}^{2}$ of potential waterbird habitat comprised of grasslands $(37.1 \%)$, pasture/hay $(24.6 \%)$, marsh $(15.9 \%)$, open wetland (11.8\%), and croplands $(10.6 \%$, Table 2). Overall, $19.5 \%$ of SONEC was potential waterbird habitat, with grasslands covering $7.2 \%$, pasture/hay $4.8 \%$, marsh $3.1 \%$, open wetlands $2.3 \%$, and croplands $2.1 \%$ (Table 2). The percentage of each subregion that was potential waterbird habitat ranged from $10.9 \%$ of Warner Valley to 33.9\% of Shasta Valley (Table 2). Grasslands comprised $22 \%$ of Shasta Valley and 5.7\%-9.5\% of other subregions. Pasture/hay comprised $10.7 \%$ of Modoc Plateau and $1.3 \%-6.9 \%$ of other subregions. Marsh comprised $7.6 \%$ of Summer Lake and $0.2 \%-$ $5.3 \%$ of other subregions. Open wetlands comprised about $7 \%$ of Modoc Plateau and Summer Lake and $0 \%-3.4 \%$ of other subregions. Croplands comprised $14.3 \%$ of the land area of Lower Klamath but only $0 \%-1.5 \%$ of other subregions.

\section{Flooded Habitat}

The percentage flooded, area flooded, and composition of flooded waterbird habitat in SONEC varied within and among years. On average, $11.9 \%$ of potential habitat in SONEC was flooded during the 4 periods that we studied (Table 2). The percentage of potential habitat flooded was greater during April-May (15.4\%) than during February (8.5\%). The percentage flooded varied greatly among habitat types, ranging during the 4 periods in SONEC from $25 \%$ to $82.9 \%(\bar{x}=65.4 \%)$ of open wetland, $2.6 \%$ to $17.5 \%(\bar{x}=10.6 \%)$ of marsh, $2.7 \%$ to $9.2 \%(\bar{x}=5.4 \%)$ of cropland, $2.1 \%$ to $6.7 \%(\bar{x}=4 \%)$ of pasture/hay, and $1.3 \%$ to $3.5 \%(\bar{x}=2.6 \%)$ of grasslands (Table 2 ).

Total flooded area and flooded area of each habitat type (except cropland in 2003) in SONEC increased during spring. Total flooding increased from $693 \mathrm{~km}^{2}$ in February to $2099 \mathrm{~km}^{2}$ in April during 2002 and from 1630 $\mathrm{km}^{2}$ in February to $2125 \mathrm{~km}^{2}$ in May during 2003 (Table 2). February flooding was greater in 2003 mostly because less open wetland was frozen than in 2002; more marsh and cropland but less grassland and pasture/hay was flooded in February 2003 than in 2002.
The composition of flooded habitats in SONEC varied only slightly within or among years. The most abundant flooded habitat in SONEC during all months was open wetland, comprising $58 \%-74 \%$ of the total flooded area (Table 2, Fig. 2). Marsh was second most abundant (except in February 2002), comprising $8 \%-18 \%$ of the flooded habitat in SONEC. Pasture/hay comprised $4 \%-11 \%$, grassland $4 \%-17 \%$, and cropland $3 \%-8 \%$ of the flooded habitat in SONEC. Marsh comprised a lower percentage of the total flooded habitat in February (8\%-9\%) than in April-May (16\%-18\%) each year whereas the opposite was true for cropland (6\%-8\% in February, 3\% in AprilMay); monthly differences were not consistent among years for the other habitats (Table 2).

Flooded habitat area differed greatly among subregions (e.g., from $<223$ ha in Pueblo Valley to $<48,464$ ha in Upper Klamath) because both the area of potential habitat (e.g., from $511 \mathrm{~km}^{2}$ in Pueblo Valley to $2434 \mathrm{~km}^{2}$ in Malheur) and the percentage of potential habitat that was flooded in each (e.g., from $0.3 \%$ in Pueblo Valley to $27.6 \%$ in Summer Lake) varied widely (Table 2). Composition of flooded habitat also differed greatly among subregions (Fig. 2). For instance, during May 2003, flooded open wetland comprised 70\%-78\% of the total available waterbird habitat in the Honey Lake, Modoc Plateau, and Summer Lake subregions; 44\%-60\% in the Lower Klamath, Upper Klamath, Shasta Valley, and Malheur subregions; but only $8 \%-30 \%$ in the other 3 subregions (Table 2, Fig. 2). Flooded cropland comprised $19 \%$ of available habitat in the Lower Klamath subregion but $<2 \%$ in most others. Pasture/hay comprised $22 \%-49 \%$ of flooded habitat in the Malheur, Northeastern California, Surprise Valley, and Pueblo Valley subregions but $<10 \%$ elsewhere. Flooded grasslands were more important in Shasta Valley (30\%) and Northeast California (24\%) than in other subregions $(<1 \%-14 \%)$. Flooded marsh comprised $<1 \%$ of available habitat in Honey Lake but 13\%-37\% in other subregions.

\section{Discussion}

\section{Temporal Variation of Flooded Habitat}

Flooding on the SONEC landscape increased during spring as increasing temperatures thawed wetlands, marshes, and other flooded areas and as melting snow and spring 


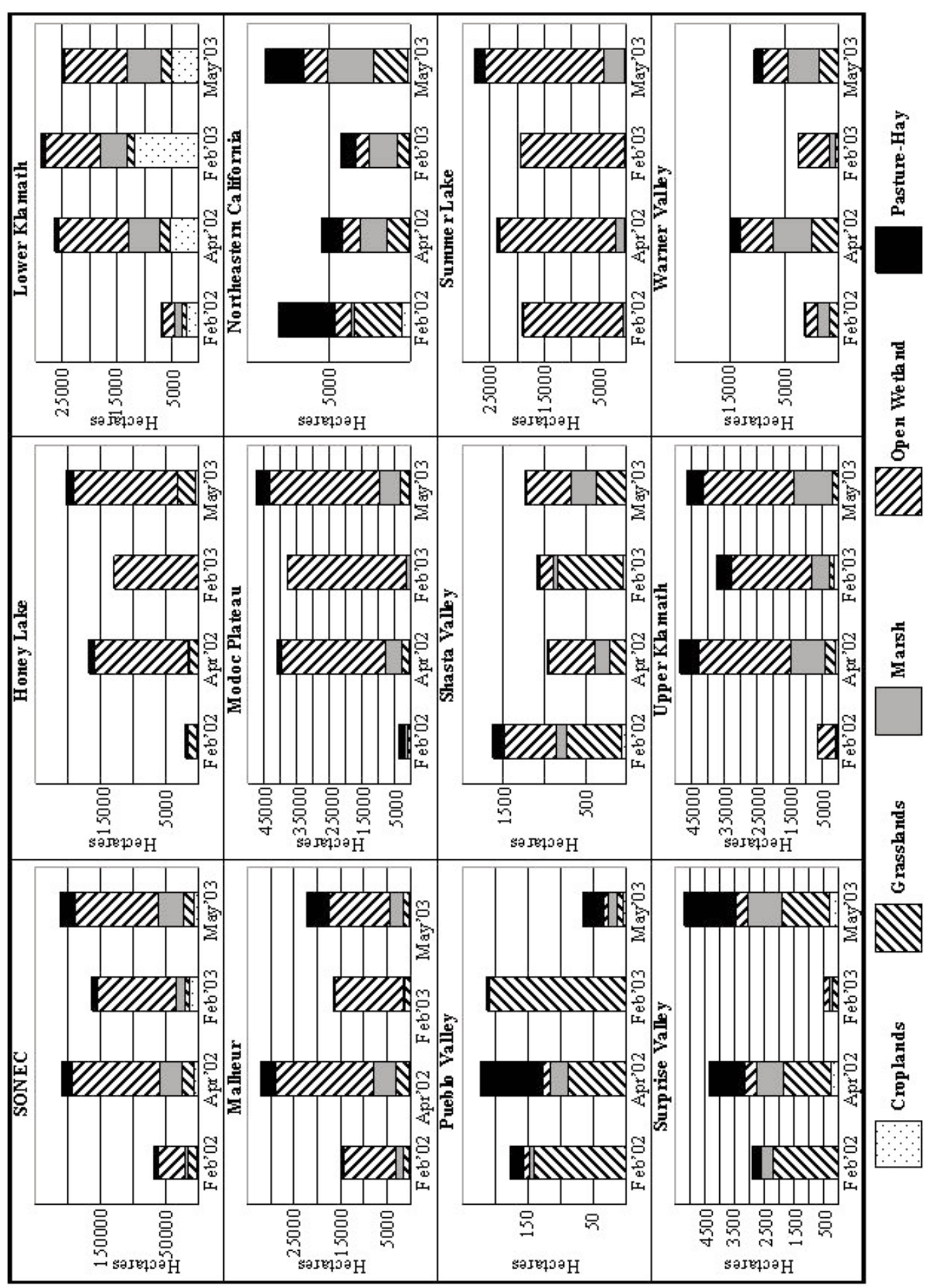

Fig. 2. Area (ha) of croplands, grasslands, marsh, open wetland, and pasture/hay in each of 10 southern Oregon-northeastern California and extreme northwestern Nevada (SONEC) subregions that was flooded during 4 sampling periods (February 2002, April 2002, February 2003, and May 2003. 
rains flooded additional areas. Area of flooded habitat in SONEC during late spring was similar in both years; but during February, flooded area in 2003 was $135 \%$ greater than in 2002 (Fig. 2, Table 2). The greater availability of February habitat in 2003 was mainly because January temperatures were warmer than average (WRCC [Internet][c], Fleskes and Battaglia 2004) and less open wetland was frozen than during February 2002. Thus, our February estimate in 2002 is probably more indicative of long-term average habitat availability in SONEC during February than our 2003 estimate.

Annual and seasonal variation in habitat availability both within and outside SONEC must be considered in conservation planning. Most waterfowl and many other waterbirds that winter in the Central Valley of California migrate through SONEC during February-May on the way to their nesting grounds, with peak abundance in SONEC generally earlier for waterfowl than for shorebirds (i.e., February-March vs. April-May; Warnock et al. 1998, Miller et al. 2005, Fleskes and Yee 2007). Preferred habitat types and foraging water depth also differs among species, with shorebirds generally foraging in a shallower range of water depths than is available to waterfowl and other waterbirds (Isola et al. 2000). Timing of waterbird spring migration and habitat availability in SONEC currently match well. However, climatic changes (Cayan et al. 2008) may alter timing of waterbird migration (Bauer et al. 2008) and increase annual variation in habitat availability above what we measured during our 2 study years of near-normal precipitation and temperatures. Also, if drought conditions become more prevalent in the Central Valley of California (Cayan et al. 2008), waterbirds may migrate into SONEC earlier and in poorer body condition. Thus, monitoring habitat availability and waterbird spring migration to detect changes and adjusting management programs to provide adequate amounts of spring habitats in SONEC may become even more important.

\section{Distribution of Potential Habitat and Flooded Habitat}

Distribution of waterbird habitat in SONEC is the result of geology and land-use practices. The types and amounts of potential and flooded waterbird habitat available in each subregion need to be considered in conservation planning for the region. For instance, deep-water habitats, such as lakes and other open wetlands, support a different cadre of waterbirds during spring than shallow-water habitats, such as flooded croplands. The capacity to flood potential habitat depends on a variety of factors including soil type and water availability. Other than marsh and open wetland, pasture/hay probably has the greatest potential for increased spring flooding because many fields were created by irrigating grasslands or altering the hydrology or vegetation of wetlands. Thus, these fields likely have waterretaining soils and water availability. Grassland probably has the lowest potential for increased spring flooding because most areas that have soils appropriate for retaining water and adequate water supplies have probably already been converted to pasture/hay or cropland.

\section{Data Limitations}

Interpretation of our results must be tempered by potential data collection and analysis problems. There are at least 3 potential sources of error inherent to our methodology that could lead to incorrect conclusions. These limitations include the currency of NLCD data, the availability of Landsat $5 \mathrm{TM}$ and Landsat 7 ETM + imagery, and our ability to classify and interpret the imagery.

NLCD-BASED HABITAT TYPES.-We classified habitat types based on 1992 NLCD data, which was the most recent NLCD data set available for the SONEC region when we conducted the analysis. Although we are not aware of expansive changes in the region, land use of some areas probably changed between 1992 and the years for which we mapped flooding (2002-2003). With federal and state wetland protection programs, conversions from one upland category to another (e.g., grassland to cropland or pasture/hay) were probably more common than conversions of marsh or open wetland to an upland category.

LANDSAT IMAGERY AVAILABILITY.-The frequency and coverage of suitable TM and ETM + imagery limited our ability to measure habitat availability in SONEC during spring. Of the 27 scenes that we used, only 17 were cloud free or nearly cloud free. These scenes were available only during early and late spring. More frequent measures of flooding may have revealed greater seasonal variation of habitat 
availability than what we measured. Also, flooding undoubtedly varies more among years than indicated by our 2 years of study during near-average weather conditions. Finally, we assumed that flooding in $8.3 \%$ of SONEC not covered by the TM and ETM+ scenes we analyzed was consistent with areas where we measured flooding; some differences may have existed.

LANDSAT IMAGERY INTERPRETATION.-Shadows and vegetation obstruction of water complicated our ability to measure flooding. Shadows, mainly from clouds, provided TM and ETM + spectral signature that overlapped with spectral signature of water. We attempted to minimize misinterpreting shadow as flooding by restricting our analysis to imagery that had no cloud shadows or minimal cloud shadows. Further, with only a few minor exceptions, we were able to avoid having to interpret the few cloud shadow areas that were present in the images by averaging the area of overlap between paths (see formula in the methods). Thus, we are confident that cloud shadow did not result in any significant overestimation of flooding.

A more difficult problem that we could not effectively eliminate was the inability of TM and ETM + sensors to detect water that was hidden by dense emergent (or other) vegetation. Our methods did generalize spectral signatures enough to correctly classify some obscured flooded areas, and ground-truthing of the Lower Klamath NWR showed that our classification of flooded marsh and wetland units was accurate. However, marsh with extremely dense emergent vegetation or other vegetation that completely obscured water reflectance would likely not be correctly classified by our method as flooded. This was probably only a severe problem for marsh, which commonly contains species of vegetation that remain erect when flooded (e.g., cattails [Typha spp.], bulrush [Scirpus spp.]), effectively obscuring water reflectance at high densities. Thus, our estimates of flooded marsh are probably biased low, and we recommend that researchers and managers use other methods to accurately determine marsh flooding.

\section{Conclusions}

Despite the limitations that we describe above, the methods we used provide useful estimates of the amount and distribution of potential and available waterbird habitat in SONEC during spring. These estimates can be used to guide habitat conservation efforts and to provide a basis for evaluating changes due to climate change, habitat programs, or other factors. SONEC's expansive land area includes a rich array of potential spring habitat for waterfowl and other waterbirds. With only about $12 \%$ of the potential habitat in SONEC flooded on average during spring, conservation programs have ample opportunity to increase flooding and improve the SONEC landscape for migrating waterbirds.

\section{ACKNOWLEDGMENTS}

We thank Mr. Tony Marnell, who through the Tuscany Research Institute of Las Vegas, Nevada, provided some operational funding for this project. The institute distributed a grant to Ducks Unlimited, Inc., in Memphis, Tennessee, which dispersed funds to the USGS Western Ecological Research Center and the California Waterfowl Association to conduct pintail research, of which this study was part. Logistical support was also provided by the USGS Western Ecological Research Center. Bill Perry and Laurie Williams provided GIS support. We also thank Mark Petrie, 2 anonymous reviewers, and the editors for their suggestions for improving the manuscript. Any use of trade, product, or firm names in this publication is for descriptive purposes only and does not imply endorsement by the U.S. government.

\section{Literature Cited}

Bauer, S., M.V. Dinther, K. Hogda, M. Klaassen, and J. Madsen. 2008. The consequences of climate-driven stop-over sites changes on migration schedules and fitness of Arctic geese. Journal of Animal Ecology $77: 654-660$.

BotTORFF, J. 1985. Concept plan for waterfowl habitat protection: Klamath Basin, Oregon and California. United States Fish and Wildlife Service, Portland, OR.

Cayan, D.R., E.P. Maurer, M.D. Dettinger, M. Tyree, AND K. HaYhoE. 2008. Climate change scenarios for the California region. Climatic Change 87:21-42.

DAHL, T.E. 2000. Status and trends of wetlands in the conterminous United States 1986 to 1997. United States Department of the Interior, Fish and Wildlife Service, Washington, DC.

Esler, D., AND D.B. GRAND. 1994. The role of nutrient reserves for clutch formation by Northern Pintails in Alaska. Condor 96:422-432.

Fleskes, J.P., and D.S. Battaglia. 2002. Pintail habitat use and abundance during spring migration in the 
Klamath Basin and other southern Oregon-northeastern California locations: progress report 2002. USDI United States Geological Survey, Western Ecological Research Center, Sacramento, CA.

2004. Northern Pintail habitat use and waterfowl abundance during spring migration in southern Oregon-northeast California (SONEC): final report. USDI United States Geological Survey, Western Ecological Research Center, Sacramento, CA.

Fleskes, J.P., W.M. Perry, K.L. Petrik, R. Spell, and F. REID. 2005. Change in area of winter-flooded and dry rice in the northern Central Valley of California determined by satellite imagery. California Fish and Game 91:207-215.

FLeskes, J.P., AND J.L. Yee. 2007. Waterfowl distribution and abundance during spring migration in southern Oregon and northeastern California. Western North American Naturalist 67:409-428.

HunT, C.B. 1967. Physiography of the United States. W.H. Freeman, San Francisco, CA.

Intermountain West Joint Venture [Internet]. Purpose: who we are: conserving habitat through partnerships [online]. Missoula, MT; [cited 26 September 2008]. Available from: http://iwjv.org/49/purpose.html

Isola, C.R., M.A. Colwell, O.W. TaFt, and R.J. SaFran. 2000. Interspecific differences in habitat use of shorebirds and waterfowl foraging in wetlands of California’s San Joaquin Valley. Waterbirds 23:196-203.

IveY, G.L., AND D.G. Paullin. 1985. Analysis of factors influencing migratory bird objectives on Malheur National Wildlife Refuge with recommendations for achieving objectives. USDI, United States Fish and Wildlife Service, Portland, OR.

Krapu, G.L. 1974. Foods of breeding pintails in North Dakota. Journal of Wildlife Management 38:408-417.

Lindstrom, A. 2003. Fuel deposition rates in migrating birds: causes, constraints and consequences. Pages 307-320 in P. Berthold, E. Gwinner, and E. Sonnenschein, editors, Avian migration. Springer-Verlag, Berlin, Germany.

Miller, M.R., AND D.C. Duncan. 1999. The Northern Pintail in North America: status and conservation needs of a struggling population. Wildlife Society Bulletin 27:788-800.

Miller, M.R., J.Y. TakekaWa, J.P. Fleskes, D.L. ORThmeyer, M.L. CasazZa, and W.M. Perry. 2005. Spring migration of Northern Pintails from California's Central Valley wintering area tracked with satellite telemetry: routes, timing, and destinations. Canadian Journal of Zoology 83:1314-1332.

Miller, M.R., J.Y. Takekawa, D.L. Orthmeyer, J.P. Fleskes, M.L. Casazza, and W.L. Perry. 2003. Final report: tracking spring migration of Northern Pintails with satellite telemetry. USDI United States Geological Survey, Western Ecological Research Center, Sacramento, CA

[NASA] National Aeronautics and Space AdministraTION. [Internet][a]. The enhanced thematic mapper plus [online]. Web site curator, Laura Rocchio; NASA official, Darrel Williams; [cited 1 July 2009]. Available from: http://andsat.gsfc.nasa.gov/about/etm + .html
[Internet][b]. The thematic mapper plus. [Cited 1 July 2009]. Available from: http://landsat.gsfc.nasa .gov/about/tm.html

North American Waterfowl Management Plan ComMITTEE. 2004. North American waterfowl management plan 2004. Strategic guidance: strengthening the biological foundation. Canadian Wildlife Service, United States Fish and Wildlife Service, Secretaria de Medio Ambiente y Recursos Naturales.

Oregon Climate Service. [Internet]. Climate of Klamath County. Oregon Climate Service, College of Oceanic and Atmospheric Sciences, Oregon State University, Corvallis, OR; [cited 25 May 2006]. Available from: http://www.ocs.orst.edu/county_climate/Klamath_ files/Klamath.html\#table1

SPELL, R., R. KempKa, AND F. REID, 1995. Evaluation of winter flooding of ricelands in the Central Valley of California using satellite imagery. Pages 357-366 in K.L. Campbell, editor, Versatility of wetlands in the agricultural landscape. American Society of Agricultural Engineers. 760 pp.

[USFWS] United States Fish and Wildlife Service. 2009. Waterfowl population status, 2009. United States Department of the Interior, Washington, DC.

[USGS EROS] United States Geological Survey Earth Resources Observation and Science Center. [Internet][a]. National land cover data. [Cited 9 September 2004]. Available from: http://edc.usgs.gov /products/landcover/nled.html

. [Internet][b]. Thematic mapper. [Cited 9 January 2006]. Available from: http://edc.usgs.gov/products /satellite/tm.html

Vogelmann, J.E., T.L. Sohl, P.V. Campbell, and D.M. SHAW. 1998. Regional land cover characterization using Landsat Thematic Mapper data and ancillary data sources. Environmental Monitoring and Assessment 51:415-428.

Warnock, N., S.M. Haig, and L.W. Oring. 1998. Monitoring species richness and abundance of shorebirds in the western Great Basin. Condor 100:589-600.

[WrCC] Western Regional Climate Center. [Internet][a]. California climate narrative. Desert Research Institute, Reno, NV; [cited 14 January 2004]. Available from: http://www.wrcc.dri.edu/narratives /CALIFORNIA.htm

[Internet][b]. Oregon climate narrative. Desert Research Institute, Reno, NV; [cited 14 January 2004]. Available from: http://www.wrcc.dri.edu/narratives/OREGON.htm

[Internet][c]. Western United States Climate Historical summaries. Desert Research Institute, Reno, NV; [cited 14 January 2004]. Available from: http:// www.wrcc.dri.edu/climsum.html

[Internet][d]. Standardized Precipitation Index. Desert Research Institute, Reno, NV; [cited 2 March 2004]. Available from: http://www.wrcc.dri.edu/spi /spi.html

Received 29 September 2008 Accepted 14 September 2009 